\title{
From the City to the Suburbs: Characteristics of Suburban Neighborhoods Where Chicago Housing Choice Voucher Households Relocated
}

\author{
Adrienne M. Holloway \\ DePaul University, 14 East Jackson Boulevard, Suite 1600, Chicago, IL 60604, USA \\ Correspondence should be addressed to Adrienne M. Holloway; ahollow4@depaul.edu
}

Received 8 February 2014; Revised 6 May 2014; Accepted 20 May 2014; Published 16 June 2014

Academic Editor: Enda Murphy

Copyright (c) 2014 Adrienne M. Holloway. This is an open access article distributed under the Creative Commons Attribution License, which permits unrestricted use, distribution, and reproduction in any medium, provided the original work is properly cited.

\begin{abstract}
The Housing Choice Voucher program (HCV) is a federally supported demand-side housing subsidy. According to HCV, eligible households are encouraged to secure affordable housing in favorable neighborhoods, including suburban neighborhoods. To what extent, however, is the supply of affordable rental housing located in suburban communities that offer favorable amenities meeting the increased demand? Using the Geography of Opportunity as a framework, this study examines the mobility results of traditional HCV households who moved from the city of Chicago to surrounding suburban neighborhoods to reveal characteristics of destination communities. Findings indicate that HCV households tend to move into suburban renter neighborhoods that have high poor, African American, and female-headed household populations. Policy makers are encouraged to consider findings to improve life outcomes of suburban HCV program participants.
\end{abstract}

\section{Introduction}

HCV is a federally funded demand-side housing subsidy. Income eligible families who receive vouchers can use the subsidy to secure housing in neighborhoods across the country. Many HCV households often choose to lease-inplace, consequently remaining in the same or similar urban neighborhoods [1]. However, public housing and community revitalization efforts that decrease housing units can restrict lease-in-place opportunities. HCV households therefore may consider suburban communities as a source for affordable rental housing.

This study examines HCV mobility within a Geography of Opportunity framework to assess the result of choices made by HCV households in selecting a suburban community in which to live. The Geography of Opportunity framework contends that housing location influences one's life outcomes. For instance, houses located in communities that have low poverty and crime rates are racially and ethnically diverse and are more likely to offer residents access to high performing schools and better employment opportunities.
Examining HCV relocation from a local context, Chicago is the focus of this study. Its experience managing various relocation programs using HCV resulted in numerous studies investigating programmatic success or failure related to intracity relocation. However, research on Chicago HCV relocation from the urban center to suburban spaces is limited. Therefore, the focus of this research is to determine whether the supply of affordable rental housing located in suburban communities, that are complete with characteristics that support positive life achievements, are the location to which Chicago HCV households move. To answer associated research questions through the Geography of Opportunity framework, this cross-sectional study statistically and descriptively compares census tracts within six counties located in the Chicago metropolitan area where Chicago Housing Authority (CHA) HCV households (the sample in this study does not include households under tenant protection vouchers or who are participating in special mobility programs.) relocated between 2000 and 2007. The study involves an assessment of the racial and ethnic composition, household composition, income, and proximity to 
employment centers of destination communities of $\mathrm{HCV}$ households.

\section{Housing Choice Voucher Program}

With the passage of the US Housing Act in 1949, the federal government assumed the responsibility of ensuring that affordable rental housing was made available to low-income persons throughout the US. Subsequently, several federal programs were developed towards this end, including the public housing development program and the programs that gave rise to the HCV program.

In 1974, President Gerald R. Ford signed into law the Housing and Community Development Act. Among other initiatives, the Act created the Section 8 certificate program (Certificate). The Certificate program, managed by the US Department of Housing and Urban Development (HUD), provided rental-housing subsidies awarded by local, state, and regional housing agencies to eligible low-income households that earned between $30 \%$ and $80 \%$ of area median income. These households, in turn, used the vouchers to secure rental housing in the private market (CBPP, 2009). Certificate holders were required to commit 30\% of their income towards the monthly rental cost of a unit as well as assume responsibility for payment of all utilities. The Public Housing Authority (PHA) that administered the voucher paid the balance of the rent, typically $70 \%$ to $110 \%$ of fair market rent (CBPP, 2009). By design, this program relied upon the private sector to provide affordable and adequate housing. The appeal of the Certificate program is that the subsidy is not place-based; instead, it travels with the client, thereby increasing the likelihood of certificate holders being able to secure housing in mixed income neighborhoods.

In 1984, congress authorized the Rental Voucher demonstration program. Though the Rental Voucher program was designed similarly to the certificate program, it included one fundamental change. In the Rental Voucher program, rental subsidies were fixed and did not adjust as rents increased, as was previous practice. The Quality Housing and Work Responsibility Act (QHWRA), which was passed in 1998, merged both programs (Certificate and Rental Voucher), creating the Housing Choice Voucher Program (HCV). Over 2.5 million HCVs are in circulation and managed by over 2,500 PHAs [2]. Each PHA is subject to an annual cap on the number of federally allocated vouchers it can administer. Although congress approves the creation of new vouchers annually, it typically only renews existing vouchers.

Since the later 1990, however, federal housing policy shifted from developing and managing affordable housing units to attempting to deconcentrate poverty in targeted communities by increasing its focus on issuing housing $\mathrm{HCV}$ to qualified households [3]. As a relocation source that capitalizes on available units in the private housing market, a unique feature of the $\mathrm{HCV}$ is portability. It enables households to move within urban neighborhoods and from urban neighborhoods to suburban and rural communities with the intention of meeting one of the $\mathrm{HCV}$ program objectives of moving from high poverty to low poverty neighborhoods (CBPP, 2009). Such moves should facilitate households' access to communities that provide high quality resources. Low income and poor households often are without adequate means in which to exercise free reign in moving to highly resourced communities with social capital building opportunities. The HCV program attempts to provide such access.

Several studies have examined mobility among households that have received HCVs [4-7]. However, results of HCV facilitated mobility remain mixed. Program critics contend that HCV holders do not relocate to high opportunity neighborhoods. On the contrary, households were found to move to neighborhoods that are either as poor or slightly less poor than their origination neighborhood [8-11] or are racially segregated [12]. On the contrary, several studies suggest that moves accomplished through $\mathrm{HCV}$ result in neighborhood satisfaction [13], moves to low poverty, low crime areas, and to neighborhoods with high employment rates $[1,14]$ and result in children of $\mathrm{HCV}$ families to be more likely to graduate from high school and attend college [15].

Three well-known federally funded mobility programs that involved the use of HCV include the Gautreaux Assisted Housing Program (Gautreaux One), the Moving to Opportunity for Fair Housing Demonstration Program (MTO), and the Gautreaux Assisted Housing Program Two (Gautreaux Two). Gautreaux One and Two and the MTO program serve as an important backdrop to the goals of this study because they all used HCVs to relocate households to high opportunity neighborhoods throughout the Chicago metropolitan area.

The Gautreaux program began in 1966 as a series of lawsuits against the CHA purporting that the agency purposefully implemented policies that segregated African American families to select Chicago neighborhoods. The courts ruled against the CHA and subsequently instructed it to implement Gautreaux in 1976. One component of the program required CHA to provide African American residents with Section 8 certificates (now HCVs) and mandated them to secure housing in low poverty desegregated areas of the metropolitan region. Participants were screened, provided with counseling, and given referrals to housing in low poverty communities over the course of the program. Over 7,500 families participated in the program where over half used the Section 8 certificates to relocate to housing in suburban communities. The program was completed in 1998.

Studies that evaluated the effects of Gautreaux program produced varying results from determining that moves availed clientele access to greater opportunities than had existed in their previous neighborhoods [16-18] to a critique of evaluation methodologies used by scholars that resulted in skewed positive results [19].

The Gautreaux experience led to other housing authorities implementing similar housing desegregation models and to the development of a national demonstration programMoving to Opportunity for Fair Housing Program (MTO). MTO was a HUD developed mobility demonstration social experiment that operated from 1994 to 1998 in Chicago, Los Angeles, Boston, Baltimore, and New York City. It 
was designed to reveal whether high-risk families realized positive outcomes if they resided in low poverty areas. The structure of the program required the 4,600 participating households to be randomly assigned to three groups: the experimental group offered families a housing voucher and housing counseling and mandated them to locate housing in neighborhoods that had no more than $10 \%$ of its population living below the poverty level. The comparison group provided families with only a housing voucher; and the control group consisted of families who remained in public housing $[20,21]$. Families were tracked over the life of the program in an effort to determine the effects of the intervention.

MTO studies also produced conflicting results. Early studies suggested that it was successful in moving experimental group families to improved neighborhoods that provided strong schools and good health outcomes $[13,22]$. Subsequent studies, however, found that the quality of the neighborhoods to which experimental families moved to was not as strong as those to which Gautreaux families moved [23] or had declined considerably over time [24]. Also, it was found that strong neighborhoods did not afford experimental families any better access to employment opportunities [24]. Ultimately, scholars contend that without ongoing counseling, experimental families were not successful in benefiting from the whole host of opportunities available in new neighborhoods.

In 2001, the CHA launched Gautreaux Two, a special mobility program for public housing residents. Similar to Gautreaux One, Gautreaux Two offered 500 public housing residents the opportunity to use HCVs to move from public housing sites to private market homes largely within the city of Chicago, that had low poverty rates and low numbers of African American households [9, 25]. However, families that initially moved into targeted neighborhoods were more found to make subsequent moves to communities that were poor and racially segregated [9].

\section{Mobility, Opportunity, and Neighborhood Effects}

Mobility via HCV subsidies is contextualized within neighborhood effects literature that examines whether neighborhood indicators affect social development of household residents $[26,27]$ and whether, particular indicators are optimal in encouraging positive life outcomes for disadvantaged households [28]. Neighborhood effects, viewed as a function of how neighbors influence behavior and attitudes of each other, are said to be transmitted through socialization, modeling, and neighborhood resources [26, 29-31].

As discussed above, a general outcome of US federal policy by way of HCV is to deconcentrate poverty, if not relocate it, as an attempt to disrupt spatial distribution of disadvantage via the promotion of mixed income neighborhood policies. Further, families who receive HCV should theoretically be able to use the voucher to secure housing in favorable socially mixed or "high-opportunity neighborhoods." Galster and killen [32] developed the Geography of Opportunity framework that includes general attributes that define high opportunity neighborhoods. The authors contend that geographic neighborhood effects influence opportunity where individuals who reside in communities that are resource deficient will experience difficulty in achieving success. Conversely, individuals who move to communities that are of high quality and offer resources geared towards achieving success will become successful. Geography of Opportunity or highopportunity neighborhoods boast strong employment levels, high employment rates, high performing school districts with better educational resources, low crime rates, a high proportion of non-Hispanic Whites, and access to extensive social and recreational resources $[6,17,20,33]$.

Suburban HCV facilitated moves, according to the Geography of Opportunity, should be to high-opportunity neighborhoods. Opportunities resulting from neighborhood effects on residents include employment gains among lowincome residents $[34,35]$, improved outcomes for children [36], and, in certain instances, access to differentiated local services [37]. Such relocation opportunities where HCV households can capitalize on suburban social and economic assets are found to produce an increase in positive life outcomes, higher efficacy, and better life chances for targeted families [30].

Generally, HCV suburban relocation is low when compared to urban relocation [38]. Urban and intracity $\mathrm{HCV}$ relocations maximize access to established social networks, economic and racial diversity, public transportation options, and more affordable housing and employment opportunities [39]. On the contrary, suburban HCV relocation is considered optimal in that it offers less dense environments, low crime rates, and better performing schools, on average [40]. However, suburban NIMBYism (Not in My Back Yard) restricts HCV relocation through collective and civic action that counters affordable housing development [41] specifically, development that is linked to minorities, the disabled, and singled family head of households using Section 8 (HCV) subsidies [42]. Consequently, access to suburban communities, though possibly desired by HCV families, is not a widespread phenomenon.

For example, Midwest HCV suburbanization is low compared to suburbanization rates in the West, South, and North [43]. Families who do relocate to the suburbs often move to inner ring suburbs as a potential residential preference to remain in close proximity to familiar urban neighborhoods and network ties $[44,45]$. However, not all suburban neighborhoods are high opportunity communities, whether inner ring suburbs or further from the urban center. Contrary to popular belief many suburbs are as poor as their urban counterparts, lack transportation access, promote racism and classism, and have limited housing options [9, 23, 33, 46, 47]. For instance, between 2000 and 2008, Covington et al. [43] found that though HCV suburbanization to neighborhoods with high employment rates and highincome levels increased, substantially more HCV families live in poor communities with limited access to jobs. Suburbs are no longer the collective epitome of economic advantage.

Accordingly, the Suburbanization of Poverty is becoming more pervasive across the country, especially in large, older 
suburban communities. Within the last several years, the nation's suburbs have become more ethnically and racially diverse and home to the largest and fastest-growing poor population in the nation $[48,49]$. Also, the suburban impoverished increasingly includes the foreign born, persons of all races, persons with limited education, and persons with limited employable skills [48].

In Chicago and its surrounding suburbs specifically, research revealed an increase in the number of extreme poverty neighborhoods defined as $20-40 \%$ of persons living below poverty [48]. Furthermore, racial and ethnic discriminatory practices from redlining to exclusionary zoning limited the migration of low-income minority families to many suburban communities $[46,50]$. Despite the fact that societal attitudes have shifted regarding overt racism and segregation in the suburbs, thereby increasing suburban minority and foreign born populations, African American and Hispanic households are still more likely to live in impoverished lowincome suburban communities [43,51].

In addition to rising poverty rates, suburban communities are also experiencing high rates of unemployment, poor health outcomes, and low educational attainment [52]. Unlike their urban counterparts, suburban communities often lack a sophisticated social service delivery system that is able to provide assistance to residents in need of income supports, job readiness, and low-cost health care [53, 54]. Though suburban communities are comprised of many opportunity neighborhoods, there are a growing number of communities that are mirroring low-income urban neighborhoods of distinctively low opportunity.

From a more narrow perspective on HCV relocation, Chicago has been the focus of numerous studies on intracity HCV mobility [22, 55-57]. Oakley and Burchfield [39] examined HCV relocation within the city of Chicago to determine if voucher families moved to qualitatively better neighborhoods. The scholars determined that voucher holders that relocated between 2000 and 2005 were concentrated in poor African American neighborhoods within the city of Chicago.

The literature on $\mathrm{CHA}$ traditional $\mathrm{HCV}$ relocation to suburban communities is on the rise [ $43,56,58,59]$. Many scholars found that the demolition of public housing resulted in an increase of suburban relocation, particularly to the inner ring suburbs $[11,60]$. This study, quasi-modeled after Oakley and Burchfield, adds to suburban literature an examination of the migration of HCV households from Chicago to neighboring suburban communities to determine whether voucher families moved to qualitatively better suburban neighborhoods. Findings from this study, in concert with results from Oakley and Burchfield's analyses, contribute to the literature a more complete perspective of the relocation outcomes of CHA voucher families who moved within the greater Chicago area.

\section{Methodology}

Research suggests that HCV households relocate to urban communities characterized as impoverished and racially and ethnically segregated $[1,12,14,61,62]$. Limited research on the suburbanization of HCV families found that householders were less likely to move to communities with high poverty rates and dense African American households [8, 38]. This research seeks to add to suburban literature analyses of $\mathrm{HCV}$ relocation to Chicago area suburbs to address the following research questions. What are the characteristics that define suburban neighborhoods to which CHA HCV households move? Are HCV suburban neighborhoods where CHA HCV households moved characteristically different than urban neighborhoods to which $\mathrm{CHA} \mathrm{HCV}$ households moved? Study findings add nuance to the literature through the utilization of a granular database detailing household characteristics of $\mathrm{HCV}$ relocated families for each year starting in 2000 and ending prior to the Great Recession in 2007. Accordingly, the additional information on households that relocate to suburban communities assists suburban stakeholders in becoming better equipped to serve this population.

4.1. Study Area and Data. To address research questions, a study area of six counties surrounding Chicago was identified (data for Cook county does not include data for the city of Chicago which is located within, DeKalb, DuPage, Kane, Will, Lake, and Will). The study area is consistent with local regional planning agencies geographic targets enabling study findings to be considered by regional stakeholders interested in housing policy and planning. Within the study area, a cross-section of active Illinois HCV households by census tract was retrieved from the US Department of Housing and Urban Development (HUD) Multifamily Tenant Characteristics System for the years 2000 to 2007 producing a database of census tracts to which Illinois 1,839 HCV households resided.

Concerns exist in the use of administrative data in research for reasons such as incomplete data records and issues with input accuracy. To produce the most accurate database possible that data was filtered further to produce a dataset that contained only data on households that relocated from Chicago to the study area. In the filtering process, accuracy was addressed by cross-referencing household cases inputted by CHA with the same household cases received by respective suburban housing authorities. Only 180 households with incongruent data across two housing authorities were eliminated from the database. Further only initial moves from Chicago to a suburban neighborhood were of interest, eliminating an additional 201 households. Any subsequent moves experienced by a household were not considered in this study. Finally, 121 households receiving tenant protection or special mobility program vouchers were removed from the database.

Through these data review processes, $502 \mathrm{HCV}$ households were eliminated from the final study database resulting in an analysis of the quality of 385 suburban census tracts (unit of analysis) to which each of the 1,337 Chicago HCV households moved. Though the sample is relatively small, it is consistent with research that has revealed that lower numbers of HCV households relocate to suburban neighborhoods visà-vis urban neighborhoods $[1,8,63]$. 
TABLE 1: Household characteristics of HCV study sample.

\begin{tabular}{|c|c|c|c|c|}
\hline $\begin{array}{l}\text { Race/ethnicity of } \\
\text { householder }\end{array}$ & Household characteristics & Bedrooms in $\mathrm{HCV}$ unit & Housing structure & Income/rent \\
\hline $\begin{array}{l}\text { African American } \\
\text { households-90\% }\end{array}$ & $\begin{array}{c}\text { Female-headed } \\
\text { Household-92\% }\end{array}$ & 0 bdrm-. $3 \%$ & Single family home $-26 \%$ & $\begin{array}{c}\text { Household annual } \\
\text { income- } \$ 10,393\end{array}$ \\
\hline $\begin{array}{l}\text { Hispanic } \\
\text { households-6\% }\end{array}$ & Disabled household-25\% & 1 bdrm- $8 \%$ & Low rise $-6 \%$ & Income range $\$ 0-\$ 50,149$ \\
\hline & $\begin{array}{l}\text { Average age head of } \\
\text { householder-40 }\end{array}$ & 2 bdrms $-28 \%$ & High rise $-63 \%$ & $\begin{array}{l}\text { Average rent to } \\
\text { owner- } \$ 950\end{array}$ \\
\hline White households-4\% & $\begin{array}{c}\text { Average household } \\
\text { size-3 }\end{array}$ & $\begin{array}{c}3 \text { bdrms }-44 \% \\
4 \text { bdrms-14\% } \\
5-6 \text { bdrms-20\% }\end{array}$ & $\begin{array}{l}\text { Rowhouse or } \\
\text { Townhouse }-5 \%\end{array}$ & Rent range $-\$ 0-\$ 1,913$ \\
\hline
\end{tabular}

Again, the study database contains relocation data from 2000 to 2007 . The beginning point of the timeframe coincides with the start of the CHA's Plan for Transformation. This plan seeks to demolish 58 public housing high-rises (a total of 35,000 units), rebuild 25,000 units, and relocate the remaining affected families utilizing vouchers. The endpoint of the study's selected timeframe (2007) precedes the beginning of the Great Recession minimizing the effect the downturn in the housing market had on study results. Finally, 2000 US Census Tract Summary File 3 data was used to gather specific characteristics of suburban destination communities.

The majority of database cases did not have origination census tract information in Chicago, preventing an urban $\mathrm{HCV}$ household origination to suburban $\mathrm{HCV}$ household destination comparison. To address this limitation, research conducted by Oakley and Burchfield [39] serves as an adequate urban comparison. Oakley and Burchfield examined 2000 and 2005 Chicago HCV data by census tract for households that relocated within the city of Chicago. Three characteristic categories (concentrated disadvantage, residential instability, and immigrant concentration) framed their analysis.

To compare HCV relocation across the urban/suburban spaces, predictor variables measured in the Oakley and Burchfield study, as well as in other studies that examined HCV mobility, were measured in this study including percentage of families in poverty [8], percentage of families receiving public assistance $[61,64]$, percentage of female headed households with children [64], percentage of African American and Hispanic residents $[8,61]$, and percentage of rental homes [65].

Proximity to employment centers serves as another viable characteristic of suburban communities and was included as a predictor variable $[43,64,66,67]$. Previous research on Chicago metropolitan area employment centers formed a database of 127 existing employment centers [68, 69]. This database was integrated with the study database to operationalize the proximity to employment opportunities variable (database usage granted by authors).

Study analyses consist of descriptive and inferential analyses (ordinary least square [OLS] regression analysis (OLS is a generalized linear modelling technique that assesses the relationship between a dependent variable $(Y)$ and a series of independent/explanatory variables $\left(X_{1}, X_{2}, \ldots, X_{n}\right)$. It is represented through a line of best-fit where any variance in the dependent variable is explained to some degree by selected explanatory variables controlling for evident interaction of said variables)). Similar to Oakley and Burchfield, the dependent variable for the regression model is the percentage of HCV households in relationship to all rental houses within a census tract. The predictor variables are stated above. The model predicts voucher housing presence among selected neighborhoods and housing characteristics. Proximity to job centers was included in the OLS regression model as a dummy variable. All census tracts located within or adjacent to a job center to which HCV households moved were assigned a value of 1 . Adjacency was measured as a 1-mile straight line from the edge of a census tract to the centroid of its closest job center to keep the measurement within a manageable walking distance and simple drive from home to work [70]. All remaining HCV households received a value of 0 indicating that the household was more than 1 mile of a job center.

\section{Results}

By providing income eligible families with housing subsidies that are mobile, the HCV program has the potential to open doors to communities and regions that may otherwise be inaccessible. As previous research has demonstrated, HCV households, particularly inner-city families, capitalize on the mobility characteristic of the program and use their voucher to secure housing in different neighborhoods, including suburban communities. The study data presented below confirms that CHA HCV families have used vouchers to move into surrounding suburban communities.

5.1. Characteristics of Chicago HCV Suburban Households. Between 2000 and 2007, 1,337 unique HCV households moved into 385 different census tracts located within a sixcounty suburban area of Chicago (see Table 1). With an average income of $\$ 10,393$ and an average family size of 3, HCV head of households that moved to the suburbs paid approximately $\$ 950$ towards rental costs. Families were also more likely to move into suburban high-rise apartments (63\%) that contained 2 to 3 bedrooms ( $72 \%$ of units) than single-family homes. Finally, $90 \%$ of the suburban HCV head 


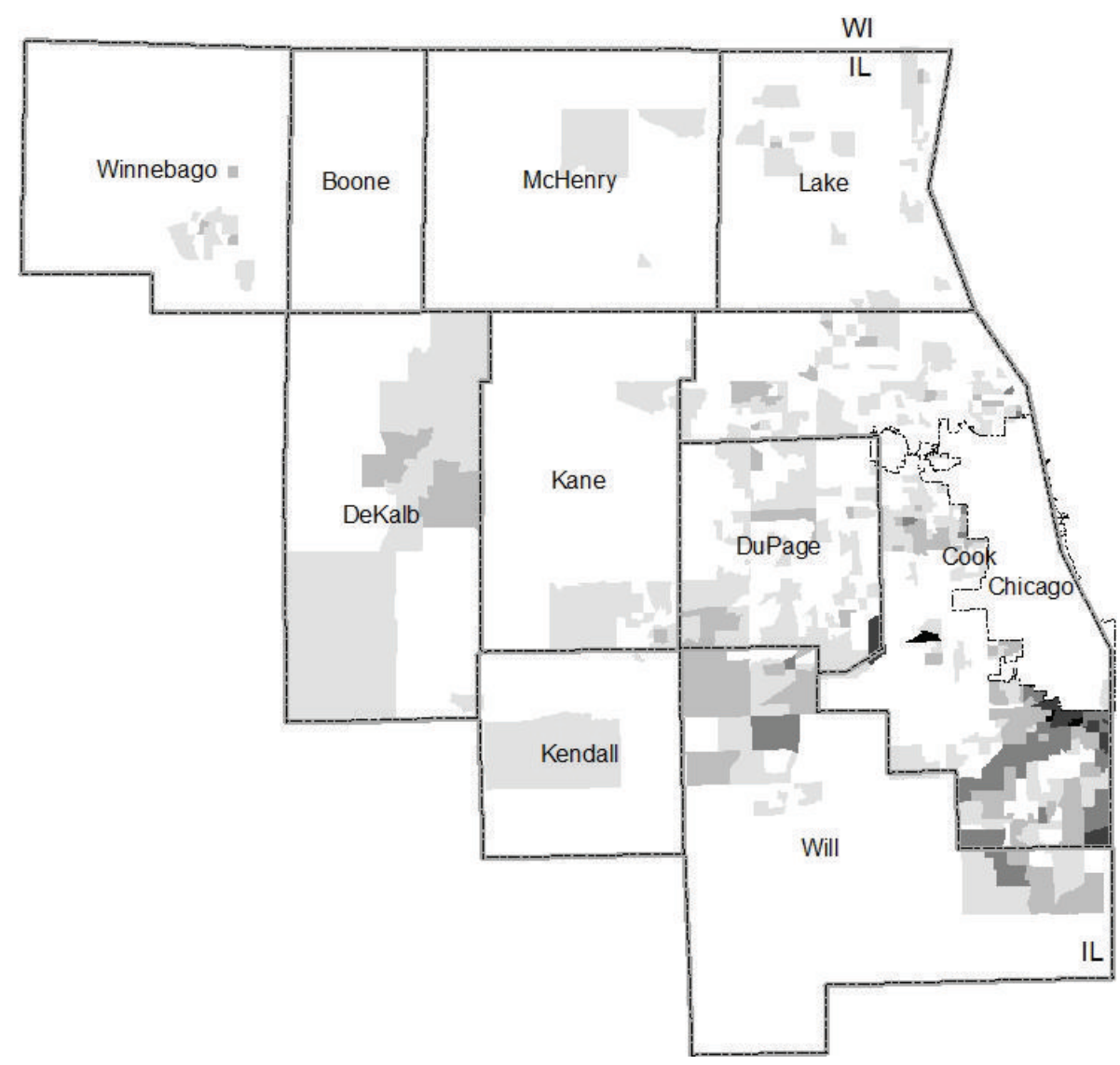

(mi)
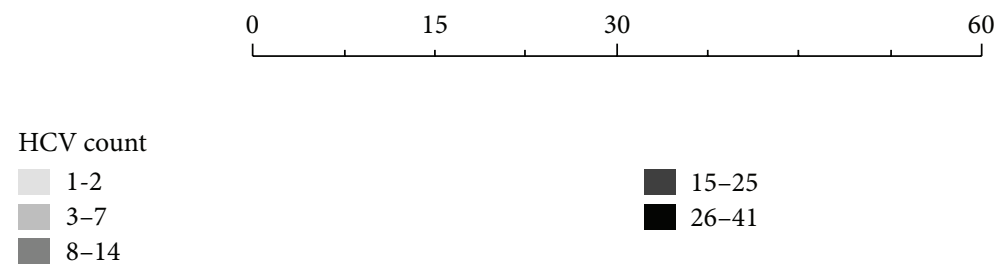

FIGURE 1: Frequency of Chicago HCV households that relocated to suburban neighborhoods.

of households were African American and 92\% were femaleheaded households with children under 18 years of age.

\subsection{Where Did Chicago HCV Households Move? Table 2} and Figure 1 present data on the percentage of relocated HCV households across the study area. The study found that the highest percentage of $\mathrm{HCV}$ households relocated to Cook county suburbs (78\%) (not including the city of Chicago). Further, all Cook county relocated households moved into less than $20 \%$ of the census tracts comprising the county. In addition to confirming previous research that $\mathrm{HCV}$ households tend to make short moves from origination to destination areas, this finding complements research on $\mathrm{HCV}$ relocation practices that occurred between 1996 and 2000. During this period, CHA demolished several public housing projects and high percentages of affected households utilized vouchers to relocate to the southernmost census tracts of Cook county $[1,6,12,63,71]$.
TABLE 2: Study area counties listed by \% of HCV relocations.

\begin{tabular}{lcc}
\hline Geography & $\begin{array}{c}\text { \% of HCV households } \\
\text { within county }\end{array}$ & $\begin{array}{c}\% \text { of county's census tracts } \\
\text { that are experiencing a } \\
\text { HCV relocation }\end{array}$ \\
\hline Cook & $78 \%$ & $18 \%$ \\
DuPage & $10 \%$ & $10 \%$ \\
Will & $6 \%$ & $35 \%$ \\
Lake & $2 \%$ & $11 \%$ \\
DeKalb & $2 \%$ & $71 \%$ \\
Kane & $2 \%$ & $24 \%$ \\
\hline
\end{tabular}

The next highest percentage of HCV movers (9\%) relocated to $42 \%$ of the census tracts comprising DuPage County. DuPage is distinctive in that it is the second most populous county (second to Cook County) and the second wealthiest 
TABLE 3: Average neighborhood characteristics of suburban HCV communities by county.

\begin{tabular}{lccccccccccc}
\hline Geography & \multirow{2}{*}{ HHI } & PP & HHPA & \multicolumn{2}{c}{ Race } & FHH & R & MHH & VU & HVC \\
\hline Cook & 50574 & 9 & 3 & 26 & 59 & 15 & 12 & 29 & 35 & 2 \\
DeKalb & 43717 & 4 & 2 & 5 & 88 & 7 & 9 & 42 & 35 & 1 & 19 \\
DuPage & 69779 & 15 & 1 & 4 & 82 & 9 & 7 & 26 & 44 & 1 & 201 \\
Kane & 49561 & 9 & 3 & 9 & 69 & 36 & 68 & 32 & 20 & .4 & 32 \\
Lake & 53867 & 9 & 3 & 12 & 69 & 26 & 12 & 29 & 42 & 1 & 79 \\
Will & 57263 & 7 & 3 & 18 & 71 & 12 & 10 & 19 & 40 & 2 & 75 \\
Entire study area & 54061 & 8 & 3 & 20 & 66 & 15 & 13 & 28 & 37 & 2 & 1337 \\
Oakley and Burchfield H/H & $*$ & 35 & 27 & 93 & $*$ & 4 & 61 & 56 & $*$ & 12 & $*$ \\
Oakley and Burchfield L/L & $*$ & 14 & 9 & 12 & & 21 & 23 & 55 & $*$ & .38 & $*$ \\
\hline
\end{tabular}

${ }^{*}$ Data not provided in Oakley and Burchfield study.

HHI: median household income; PP: percent population below poverty; HHPA: percent households receiving public assistance; race: B: percent black population; W: percent white population; H: percent Hispanic population; FHH: percent female-headed households; R: percent renter; HVU: percent of voucher units by renter units; HVC: housing voucher count.

county in Illinois (second to Lake County). DuPage is also the primary county for 38 municipalities in the Chicago metropolitan region that collectively contributes $40 \%$ of the jobs to the Chicago metro region and employs over $30 \%$ of the Chicago metro region's workforce. In addition, DuPage county is comprised of many social service providers and networks. Moreover, DuPage County's adjacency to Cook County may have contributed to HCV households deciding to bypass Cook County and continue west towards DuPage County.

The census tracts where CHA HCV households moved were not overwhelmingly renter communities. Collectively the suburban census tracts where HCV families relocated were comprised of $28 \%$ of renter households. The census tracts in Dekalb, where the smallest number of HCV households moved (19), contained the highest percentage of renters (42\%). On the contrary, only $29 \%$ of the census tracts in Cook County, where the largest number of HCV families moved, were comprised of renter households.

\subsection{Which Characteristics Describe HCV Suburban Neighborhoods?}

5.3.1. Income. The median household income (HHI) of census tracts per county within the study area to which $\mathrm{HCV}$ households relocated ranged from $\$ 23,850$ in Cook county to $\$ 162,155$ in DuPage county (see Table 3 ). The median HHI for all DuPage county census tracts was the highest compared to other counties. In relationship to poverty, DeKalb census tracts where HCV households moved had the highest percentage of impoverished persons (15\%). HCV households that moved into DuPage, however, lived in census tracts with approximately $4 \%$ of its respective population living below the poverty line. Collectively, the average percent of people living below the poverty line for the study area was $8 \%$. HCV destination communities where the highest percentage of households receiving public assistance were located in Cook county (3.2\%). DeKalb had the lowest percentage of public assistance receiving households (1.72). Data suggests that study area census tracts exhibited a wide range of income diversity.

5.4. Population Characteristics. The population of study area census tracts was largely Whites (see Table 3). DeKalb's census tracts where HCV households moved had the highest percentage of white households (88\%) and Cook's census tracts were HCV households moved had the lowest percentage of white households (59\%). The census tracts to which HCV households moved that had the highest percentage of African Americans were located in Cook (26\%) and the census tracts to which HCV households moved that had the highest percentage of Hispanics were located in Kane county (36\%). Further, HCV households moved into census tracts that were largely comprised of married families with children (37\%). Kane county census tracts to which HCV households moved had the highest percentage of female-headed households (68\%).

One-way ANOVA analyses were performed for all census tracts by county groups for each independent variable. Findings were significant across all independent variables suggesting that at least two of the census tract groupings by county were significantly different from one another (see Table 4). Post hoc tests were computed and, among other relationships, Cook county and DuPage county had the highest number of significantly different means across all independent variables. One can postulate that the neighborhoods that HCV households moved to in Cook county are characteristically different compared to the neighborhoods HCV households relocated to in DuPage county.

Oakley and Burchfield examined characteristics of high voucher density and low voucher density Chicago communities to which HCV households moved. Many differences exist between the HCV household urban relocation experience, as presented by Oakley and Burchfield, and the suburban relocation experience included in this study. Oakley and Burchfield's findings suggest that high voucher neighborhoods were more likely to be comprised of high percentages of rental housing (56\%), African American households 
TABLE 4: Characteristic differences between HCV communities by county: results of ANOVA and Tukey HSD Post Hoc test.

\begin{tabular}{lccccc}
\hline Geography & Cook & DeKalb & DuPage & Kane & Lake \\
\hline Cook & & $2,4,5,9$ & $1,2,3,4,5,7,8$ & 6,7 & 6,8 \\
DeKalb & $2,4,5,9$ & & $1,2,8,9$ & 6,7 & 6,8 \\
DuPage & $1,2,3,4,5,7,8$ & $1,2,8,9$ & & $1,6,7$ & $1,2,9$ \\
Kane & 6,7 & 6,7 & $1,6,7$ & $1,6,7$ & \\
Lake & 6,8 & 6,8 & $1,2,6,7$ & 6,7 \\
Will & 9 & $1,2,9$ & 1 & 6,7 & 6,7 \\
\hline
\end{tabular}

1: Median income $(F=14.733 ; P<.000)$.

2: Poverty $(F=8.045 ; P<.000)$.

3: $\operatorname{HHPA}(F=5.061 ; P<.000)$

4: Black $(F=10.344 ; P<.000)$.

5: White $(F=13.220 ; P<.000)$.

6: Latino $(F=10.477 ; P<.000)$.

7: $\mathrm{FHH}(F=213.593 ; P<.000)$.

8: $\mathrm{MHCH}(F=14.733 ; P<.000)$

9: $\operatorname{Renter}(F=4.726 ; P<.000)$.

(93\%), and female-headed households with children (61\%). Income disadvantage also characterized HCV communities confirmed by rather high percentages of poverty $(35 \%)$ and public assistance (27\%).

HCV suburban neighborhoods, by comparison, scored much lower on all independent variables compared to Chicago's high voucher and low voucher density communities (see Table 3). For instance, suburban census tracts experienced lower poverty rates $(15 \%)$, percentages of households receiving public assistance (3\%), percentages of African American families (36\%), and less renter households (32\%). The female-headed household with children variable, however, was higher in one suburban county (Kane) at $68 \%$ surpassing both Chicago high voucher and low voucher density communities. Also worth noting, the suburban presence of African American families was higher in selected HCV communities when compared to low voucher communities in Chicago. Despite the few exceptions, one may conclude from the comparisons that the suburban neighborhoods to which HCV household moved are less disadvantaged than the urban neighborhoods where CHA HCV households relocated.

Notwithstanding the urban/suburban differences, another intent of this study was to determine whether HCV households moved to suburban communities that can be characterized as opportunity neighborhoods. An OLS regression analysis was performed to determine which characteristics (independent variables) are strong predictors of $\mathrm{HCV}$ presence and whether significant predictor variables are aligned with characteristics of opportunity neighborhoods.

The best fit regression model produced from study variables revealed the combination of independent variables that provided the strongest predictive power to be the percent of a communities African American population, households receiving public assistance, persons living below the poverty level, and rental units $(F=50.936, P<.001)$ (see Table 5). The $R^{2}$ value of .349 indicates an acceptable fit of the model. Predictor variables that were not found to be significant include percentage of female-headed households with children, percentage of Hispanic population, and proximity to job centers. Similar to Oakley and Burchfield, significant predictor variables are associated with disadvantaged neighborhood characteristics. Collectively, study findings suggest that suburban HCV households relocate to communities that are more likely opportunity neighborhoods when compared to urban HCV household communities. However, when considering only suburban neighborhood comparisons, characteristics aligned with disadvantage are a strong predictor of $\mathrm{HCV}$ relocation.

\section{Discussion}

This study examined suburban relocation by HCV households to reveal characteristics of the neighborhoods to which housing was secured. The suburban community variables examined in this study, identified as opportunity variables, were race/ethnicity (African American, White, Hispanic), income (household median income, population living below poverty, and population receiving public assistance), household composition (married and female-headed households), and neighborhood characteristics (rental units and employment proximity).

Study findings show that HCV households were more likely to move to suburban communities characterized as largely rental communities with high numbers of African American households, of people living below poverty, and of people receiving public assistance. Though relocation to suburban communities produced better results when compared to HCV relocation within Chicago [39], suburban relocation must also be viewed within its separate geographic context. Given the number of communities that comprise suburban Chicago, HCV families that moved into Chicago suburban communities were more likely to have moved to suburban disadvantaged communities rather than suburban opportunity communities. Implications of HCV suburban relocation to such communities are plentiful.

Findings suggest that HCV households are not moving to suburban communities that are in close proximity to established job centers. The Spatial Mismatch Hypothesis is a possible explanation for the lack of a job center pull effect [72]. 
TABLE 5: OLS regression results.

(a) Model summary

\begin{tabular}{ccccc}
\hline & $R$ & $R$ square & Adjusted $R$ square & Std. error of the estimate \\
\hline Model & $.591^{\mathrm{d}}$ & .349 & .342 & 1.7229951 \\
\hline d $_{\text {Predictors: (constant) }}$ \% & \% & \%
\end{tabular}

(b) ANOVA $^{\mathrm{a}}$

\begin{tabular}{lccccc}
\hline & Sum of squares & df & Mean square & $F$ & Sig. \\
\hline Regression & 604.852 & 4 & 151.213 & 50.936 & $.000^{\mathrm{e}}$ \\
Residual & 1128.111 & 380 & 2.969 & & \\
\hline Total & 1732.963 & 384 & & & \\
\hline
\end{tabular}

${ }^{\mathrm{a}}$ Dependent variable: RDV.

${ }^{\mathrm{e}}$ Significant at the $P<.000$ level.

(c) Coefficients ${ }^{\mathrm{a}}$

\begin{tabular}{|c|c|c|c|c|c|}
\hline & \multicolumn{2}{|c|}{ Unstandardized coefficients } & \multirow{2}{*}{$\begin{array}{c}\text { Standardized coefficients } \\
\text { Beta }\end{array}$} & \multirow{2}{*}{$t$} & \multirow{2}{*}{ Sig. } \\
\hline & $B$ & Std. Error & & & \\
\hline (Constant) & 1.712 & .178 & & 9.594 & .000 \\
\hline \%Black & .044 & .004 & .562 & 10.495 & .000 \\
\hline$\%$ Renter & 051 & .007 & .408 & 7.769 & .000 \\
\hline$\% \mathrm{HH}$ receiving public assistance & .260 & .048 & .363 & 5.413 & .000 \\
\hline \%Population below poverty & .090 & .020 & .309 & 4.491 & .000 \\
\hline
\end{tabular}

${ }^{\mathrm{a}}$ Dependent variable: $\mathrm{HCV}$.

Often used to explain limited access to suburban jobs from inner city communities where low skill workers resided [73], the Spatial Mismatch Hypothesis sheds light on why HCV households where not relocating in large numbers to established job centers in the suburbs. HCV households, living in suburban spaces, should no longer be limited in their ability to be employed as they share location with employers, as per the hypothesis. While research has demonstrated this to be true, particularly for low-income, African American males $[16,74]$, other present barriers to employment counter the access basis of the Spatial Mismatch Hypothesis.

Within the context of research findings, residential communities adjacent to Chicago suburban job centers may be engaging in housing discriminatory practices that limit access to housing units by low income/poor (HCV) persons [75]. In other words, HCV household relocation may not have occurred near established job centers due to persistent suburban economic discrimination. In addition, research suggests that other barriers make securing employment in suburban job centers challenging, including access to public transportation, child care, racial discrimination, and having the skill set required for suburban jobs [35].

HCV households are also more likely to relocate to neighborhoods with high concentrations of African American households. Census tracts that contained high percentages of Hispanics, however, were not found to be locations to which high numbers of HCV households relocated. Though African American households are overrepresented among the renter populations, and similarly among the HCV households examined in this study (see Table 1), the high concentration of African American households in $\mathrm{HCV}$ suburban census tracts may also be a function of prevailing segregation. Census tracts examined in this study revealed higher percentages of White residents.

It is likely that the profusion of HCV households in large African American communities is a function of persistent segregation and racial discrimination. Accordingly, research findings support scholars who argue that African American segregation in suburban communities remains disproportionately high $[43,76]$. Further, African American households are often subjected to landlord discrimination when attempting to secure housing [77]. It is probable that African Americans HCV households that attempt to secure housing in integrated census tracts are unsuccessful due to landlord bias and racial discrimination. Finally, suburban census tracts that have high Hispanic populations are more likely to be of higher income, which may explain the low presence of HCV households.

Research also suggests that African Americans are more likely to live in poor and minority neighborhoods [7880]. The general income characteristics of study area HCV suburban communities were found to be, on average, lower than surrounding suburban neighborhoods. Consequently, HCV families are more likely to move to communities with large numbers of families living below the poverty line and receiving public assistance. Scholars assert that higherincome communities do not have a high volume of affordable housing units to rent to HCV households and that lower income communities are more inclined to meet the affordable housing demand $[1,14]$. While HCV Chicago neighborhoods may also be poor, this study confirms that use of HCV to relocate to suburban neighborhoods may not result in entry 
to above poverty neighborhoods. The higher the household income of a census tract, the less likely one will find an HCV household.

The supply of rental housing units often relies upon local decision-making processes and zoning practices, which can be purposefully designed to constrict the availability of rental housing units in suburban communities. Rental housing units that are offered through multifamily housing development are subjected to the specific zoning criteria set forth by each municipality. Municipalities interested in limiting the number of rental housing units will make the development of multifamily housing, particularly affordable multifamily housing, cost prohibitive for a developer. Developers that do embark on multifamily housing development will attempt to develop units that, when priced in the market, will absorb associated high development costs in order to turn a profit. Often rental units developed according to this strategy are unaffordable to HCV households. A study on DuPage County Illinois found that there was less evidence of HCV household concentration in communities that had restrictive multifamily zoning [81].

Consequences associated with poverty concentration and racial segregation in urban and suburban communities are vast. Wilson [73] contends that social isolation does not afford low income households, African Americans in particular, contact with successful social networks, access to highly regarded employment opportunities, and the opportunity to move into the middle class. Elevated crime, poor school performance, and widespread community disinvestments are additional consequences associated with residing in segregated and poor communities [82]. Similar results are likely in suburban spaces if policy shifts do not occur.

Along with challenges in securing housing in suburban opportunity communities are identifying and accessing human, social, and public services in suburbia. Research reveals that the identification of and access to suburban service organizations are challenging and problematic $[52,53$, 83]. Consequently, a HCV move to a suburban community may also limit household members' receipt of much needed supportive services, potentially making improving life outcomes of HCV household residents much more challenging.

\section{Limitations of Research and Recommendations for Future Research}

This study contributes valuable findings to housing literature. Additional studies are recommended, specifically, research using large samples sizes to confirm whether HCV households are moving into segregated suburban communities in large numbers. The additional research findings will determine if the choice factor in the $\mathrm{HCV}$ program is being exercised without barriers. If choice is consistently suppressed, then policy action needs to be taken that will open more communities to HCV households.

Additional variables, particularly those associated with social services of particular interest or need, as determined by HCV families, should be identified and analyzed in future research. For instance, it would be interesting to assess whether access to child-care centers and recreational opportunities serve as pull factors for HCV households. Further, variables that include healthcare services will aid in determining whether HCV families are locating within communities that provide them with low-cost healthcare options.

Statistical analyses alone are not sufficient in identifying with certainty the rationale behind one's decision to selfselect to communities. Mixed methods involving qualitative research will glean specific anecdotal findings on the decision equations used by $\mathrm{HCV}$ families in determining which community to move. Combined with quantitative research, proposed mixed method studies will produce evidence that is more robust about the geographic factors that will lead to success.

\section{Policy Suggestions}

8.1. Affordable Housing Access and Development. Study results provide scholars with nuanced information on the $\mathrm{HCV}$ relocation challenges associated with a population that differs from similar studies. Unlike the Gautreaux One, Gautreaux Two, MTO, and HOPE VI special HCV mobility programs, traditional HCV households do not receive services designed to aid them in and through the relocation process. For instance, traditional HCV households are not provided with housing counseling and guidance in the identification and processing of rental housing or in the evaluation of potential communities that special mobility populations receive. Thus, traditional HCV households are often required to make important relocation decisions with little valuable information. Notwithstanding limited access to opportunity communities resulting in race and economic discrimination, housing location choices can be improved with access to viable and valuable community information. Accordingly, housing counseling must also be made available for traditional HCV households to aid households in securing housing in suburban opportunity neighborhoods.

The limited supply of affordable housing units that characterizes suburban spaces, resulting from persistent exclusionary zoning practices, also impedes access to suburban communities [84-86]. Remedies exist to address limited affordable housing units, particularly in suburban America. Massachusetts, Connecticut, and Rhode Island provide examples of legislation aimed at increasing affordable housing production through development mandates and streamlined approval processes [87]. In 2003, Illinois passed the Affordable Housing Planning and Approval Act (AHPAA) that encouraged Illinois municipalities that were found to have less than $10 \%$ of housing affordable to working class families (as per HUD adopted guidelines) to submit plans dictating procedures to incorporate affordable housing within their respective jurisdictions [88].

Forty-nine of the 1,287 municipalities were identified as not exempt from the law and thus were encouraged to submit plans. Forty-six of the 49 nonexempt municipalities are located within the target area of this study [88]. Further, as of 2011, 12 of the 46 nonexempt municipalities have yet to 
submit an affordable housing plan [88]. Though the law is a victory in and of itself, it does not contain any enforcement powers and, accordingly, no ability to impose consequences for noncompliant communities. In addition, municipalities that have complied with the law and submitted plans are not compelled to implement them, as there are no consequences associated with nonactivity. If Illinois is to realize an equitable increase in the distribution of affordable housing across the state, lawmakers must revise the elements of the AHPAA to include, preferably, economic consequences for nonompliance. Relying upon the "good will" of municipalities is likely to maintain the status quo.

8.2. Racism and Classism. Data from this study suggests that racism and classism, in particular, oppressive behavior that is made evident through overt, conscious actions and conduct as well as through unconscious, insidious attitudes and perspectives, limits access to the wider suburban geography. Consequently, existing public policies, in the form of housing policies and the HCV Program, are not capable of achieving stated goals of moving persons to diverse, less impoverished communities. Government, from equity and social justice positions, should invest resources and take deliberate action to eliminate such barriers so that targeted groups enjoy the opportunity of choosing communities in which to live, without being subjected to unfair practices.

Continuous funding of mobility programs is a method that can achieve long-term success in economic and racial integration of particular regions. Annual funding levels of the HCV program have been on a continuous decline for several years. Recent federal government sequestration cuts and other funding cuts resulted in a decline of $\$ 854$ million in funding and an estimated $140,000 \mathrm{HCV}$ that were not renewed for 2013 [89]. Declining HCV budgets thwarts integration efforts availed by the program. Consistent funding enables local public housing authorities to renew vouchers for eligible households and award additional vouchers to new households, ultimately increasing integrated settlement patterns in targeted areas.

8.3. Suburban Social Safety Net. Philanthropic organizations that contribute to the budgets of service organizations have not fully acknowledged the increase service need in suburbia [90]. Consequently, suburban safety net organizations are experiencing difficulty in securing additional financial support to meet increased need. Study findings contribute to the literature on suburban poverty that will inform policy makers and philanthropic organization of the legitimate the need to increase funding support of suburban safety net programs.

In closing, a move to the suburbs by HCV families is not a guaranteed "step-up" along the opportunity ladder until decision makers commit to support and fund appropriate and effective programs and policies for suburban communities.

\section{Conflict of Interests}

The author declares that there is no conflict of interests regarding the publication of this paper.

\section{References}

[1] J. D. Feins and R. Patterson, "Geographic mobility in the housing choice voucher program: a study of families entering the program, 1995-2002," Cityscape, vol. 8, no. 2, pp. 21-47, 2005.

[2] http://www.hud.gov/budgetsummary2011/index.cfm.

[3] G. C. Galster, "U.S. housing scholarship, planning, and policy since 1968: an introduction to the special issue," Journal of the American Planning Association, vol. 74, no. 1, pp. 5-16, 2008.

[4] L. Buron, D. K. Levy, and M. Gallagher, How HOPE VI Families Fared in the Private Market, The Urban Institute, Washington, DC, USA, 2007.

[5] M. L. Leger and S. D. Kennedy, Final Comprehensive Report of the Freestanding Housing Voucher Demonstration, vol. 1, U.S. Department of Housing and Urban Development, Washington, DC, USA, 1990.

[6] S. J. Popkin and M. K. Cunningham, Searching for Rental Housing with Section 8 in the Chicago Region, The Urban Institute, Washington, DC, USA, 2000.

[7] M. A. Turner and S. J. Popkin, Why Housing Choice and Mobility Matter, The Urban Institute, Washington, DC, USA, 2010.

[8] D. J. Devine, R. W. Gray, L. Rubin, and L. B. Taghavi, Housing Choice Voucher Location Patterns: Implications for Participant and Neighborhood Welfare, U.S. Department of Housing and Urban Development, Washington, DC, USA, 2003.

[9] M. L. Boyd, K. Edin, S. Clampet-Lundquist, and G. J. Duncan, "The durability of gains from the gautreaux two residential mobility program: a qualitative analysis of who stays and who moves from low-poverty neighborhoods," Housing Policy Debate, vol. 20, no. 1, pp. 119-146, 2010.

[10] V. Basolo and M. T. Nguyen, "Does mobility matter? The neighborhood conditions of housing voucher holders by race and ethnicity," Housing Policy Debate, vol. 16, no. 3-4, pp. 297324, 2005.

[11] W. A. V. Clark, "Reexamining the moving to opportunity study and its contribution to changing the distribution of poverty and ethnic concentration," Demography, vol. 45, no. 3, pp. 515-535, 2008.

[12] L. Bennett, J. L. Smith, and P. A. Wright, Eds., Where Are the Poor People to Live? Transforming Public Housing Communities, M. E. Sharpe, New York, NY, USA, 2006.

[13] T. Leventhal and J. Brooks-Gunn, "Moving to oppurtunity: an experimental study of neighborhood effects on mental health," The American Journal of Public Health, vol. 93, no. 9, pp. 15761582, 2003.

[14] C. G. Climaco, C. N. Rodger, J. D. Feins, and K. Lam, "Portability moves in the housing choice voucher program, 1998-2005," Cityscape, vol. 10, no. 1, pp. 21-47, 2008.

[15] G. Mills, D. Gubits, L. Orr et al., Effects of Housing Vouchers on Welfare Families: Final Report: Prepared for the U.S. Department of Housing and Urban Development, Office of Policy Development and Research, Abt Associates, Cambridge, Mass, USA, 2006.

[16] J. E. Rosenbaum and S. J. Popkin, "Employment and earnings of low-income blacks who move to middle-class suburbs," in The Urban Underclass, C. Jencks and P. E. Peterson, Eds., Brookings Institution, Washington, DC, USA, 1991.

[17] J. E. Rosenbaum, "Changing the geography of opportunity by expanding residential choice: lessons from the gautreaux program," Housing Policy Debate, vol. 6, no. 1, pp. 231-269, 1995. 
[18] L. S. Rubinowitz and J. E. Rosenbaum, Crossing the Class and Color Lines: From Public Housing to White Suburbia, University of Chicago Press, Chicago, Ill, USA, 2000.

[19] J. Goering, Expanding Housing Choices For HUD-Assisted Families: Moving to Opportunity For Fair Housing Demonstration, First Biennial Report to Congress, U.S. Department of Housing and Urban Development, Washington, DC, USA, 1996.

[20] X. Briggs, "More pluribus, less unum? The changing geography of race and opportunity," in The Geography of Opportunity: Race and Housing Choice in Metropolitan America, X. de Souza Briggs, Ed., Brookings Institution Press, Washington, DC, USA, 2005.

[21] G. J. Duncan and A. Zuberi, "Mobility lessons from gautreaux and moving to opportunity," Northwestern Journal of Law and Social Policy, vol. 1, no. 1, pp. 110-126, 2006.

[22] J. Goering, J. D. Feins, and T. M. Richardson, "A cross-site analysis of initial moving to opportunity demonstration results," Journal of Housing Research, vol. 13, pp. 1-30, 2002.

[23] X. Briggs, S. Popkin, and J. Goering, Moving to Opportunity: The Story of an American Experiment to Fight Ghetto Poverty, Oxford University Press, Oxford, UK, 2010.

[24] S. J. Popkin, New Findings on the Benefits and Limitations of Assisted Housing Mobility, The Urban Institute, Washington, DC, USA, 2008.

[25] J. M. Reed, J. Pashup, and E. K. Snell, "Voucher use, labor force participation, and life priorities: findings from the gautreaux two housing mobility study," Cityscape, vol. 8, no. 2, pp. 219-239, 2005.

[26] A. Kearns, "Response: from residential disadvantage to opportunity? Reflections on British and European policy and research," Housing Studies, vol. 17, no. 1, pp. 145-150, 2002.

[27] W. Ostendorf, S. Musterd, and S. de Vos, "Social mix and the neighbourhood effect: policy ambitions and empirical evidence," Housing Studies, vol. 16, no. 3, pp. 371-380, 2001.

[28] J. Friedrichs, G. Galster, and S. Musterd, "Neighbourhood effects on social opportunities: the European and American research and policy context," Housing Studies, vol. 18, no. 6, pp. 797-806, 2003.

[29] T. Leventhal and J. Brooks-Gunn, "The neighborhoods they live in: the effects of neighborhood residence on child and adolescent outcomes," Psychological Bulletin, vol. 126, no. 2, pp. 309-337, 2000.

[30] J. E. Rosenbaum, L. Reynolds, and S. DeLuca, "How do places matter? The geography of opportunity, self-efficacy and a look inside the black box of residential mobility," Housing Studies, vol. 17, no. 1, pp. 71-82, 2002.

[31] R. J. Sampson, J. D. Morenoff, and T. Gannon-Rowley, "Assessing "neighborhood effects": social processes and new directions in research," Annual Review of Sociology, vol. 28, pp. 443-478, 2002.

[32] G. C. Galster and S. P. Killen, "The geography of metropolitan opportunity: a reconnaissance and conceptual framework," Housing Policy Debate, vol. 6, no. 1, pp. 7-43, 1995.

[33] M. A. Turner, A. Nichols, J. Comey, K. Franks, and D. Price, Benefits of Living in High Opportunity Neighborhoods: Insights from the Moving to Opportunity Demonstration, The Urban Institute, Washington, DC, USA, 2012.

[34] S. Musterd and R. Andersson, "Employment, social mobility and neighbourhood effects: the case of Sweden," International Journal of Urban and Regional Research, vol. 30, no. 1, pp. 120 140, 2006.
[35] S. J. Popkin, J. E. Rosenbaum, and P. M. Meaden, "Labor market experiences of low-income black women in middleclass suburbs: evidence from a survey of gautreaux program participants," Journal of Policy Analysis and Management, vol. 12, no. 3, pp. 556-573, 1993.

[36] C. Jenks and S. Mayer, "The social consequences of growing up in a poor neighborhood," in Inner-City Poverty in the United States, L. E. Lynn and M. F. H. McGeary, Eds., pp. 111-186, National Academy Press, Washington, DC, USA, 1990.

[37] A. Murie and S. Musterd, "Social exclusion and opportunity structures in European cities and neighbourhoods," Urban Studies, vol. 41, no. 8, pp. 1441-1459, 2004.

[38] M. M. Galvez, What do We Know About Housing Choice Voucher Program Location Outcomes? A Review of Recent Literature, The Urban Institute, Washington, DC, USA, 2010.

[39] D. Oakley and K. Burchfield, "Out of the projects, still in the hood: the spatial constraints on public-housing residents'relocation in Chicago," Journal of Urban Affairs, vol. 31, no. 5, pp. 589-614, 2009.

[40] M. Keels, "The importance of scaffolding the transition unpacking the null effects of relocating poor children into nonpoor neighborhoods," The American Educational Research Journal, vol. 50, no. 5, pp. 991-1018, 2013.

[41] S. Vandehey, "Civics in the suburbs: where NIMBYism reflects community," Boom: A Journal of California, vol. 3, no. 2, pp. 52 71, 2013.

[42] K. L. Patterson and R. M. Silvermanb, "How local public administrators, nonprofit providers, and elected officials perceive impediments to fair housing in the suburbs: an analysis of Erie County, New York," Housing Policy Debate, vol. 21, no. 1, pp. 165188, 2011.

[43] K. Covington, L. Freeman, and M. Stoll, The Suburbanization of Housing Choice Voucher Recipients, Brookings Institution, Washington, DC, USA, 2011.

[44] W. A. V. Clark, "Intervening in the residential mobility process: neighborhood outcomes for low-income populations," Proceedings of the National Academy of Sciences of the United States of America, vol. 102, no. 43, pp. 15307-15312, 2005.

[45] S. Thernstrom and A. Thernstrom, America in Black and White: One Nation, Indivisible, Touchstone Books, New York, NY, USA, 1997.

[46] B. N. Ross and M. A. Levine, Urban Politics: Cities and Suburbs in a Global Age, M.E. Sharpe, Armonk, NY, USA, 8th edition, 2012.

[47] H. Schwartz, L. Ecola, K. J. Leuschner, and A. Kofner, Is Inclusionary Zoning Inclusionary? RAND Corporation, Santa Monica, Calif, USA, 2012.

[48] E. Kneebone and A. Berube, Confronting Suburban Poverty in America, Brookings Institution, Washington, DC, USA, 2013.

[49] E. Kneebone and E. Garr, The Suburbanization of Poverty: Trends in Metropolitan America, 2000 to 2008, Brookings Institution, Washington, DC, USA, 2010.

[50] D. Kaplan and F. Douzet, "Research in ethnic segregation III: segregation outcomes," Urban Geography, vol. 32, no. 4, pp. 589605, 2011.

[51] D. Trisi, A. Sherman, and M. Broadous, Poverty Rate Second Highest in 45 Years, Record Numbers Lacked Health Insurance Lived in Deep Poverty, Center on Budget and Policy Priorities, Washington, DC, USA, 2011.

[52] A. K. Murphy, "The suburban ghetto: the legacy of herbert gans in understanding the experience of poverty in recently 
impoverished American suburbs," City and Community, vol. 6, no. 1, pp. 21-37, 2007.

[53] S. W. Allard and B. Roth, Strained Suburbs: The Social Service Challenge of Rising Suburban Poverty, Brookings Institution, Washington, DC, USA, 2010.

[54] R. Puentes and M. Orfield, Valuing America's First Suburbs: A Policy Agenda for Older Suburbs in the Midwest, Brookings Institution, Washington, DC, USA, 2002.

[55] G. C. Galster, "US assisted housing programs and poverty deconcentration: a critical geographic review," in Neighbourhood Effects or Neighbourhood Based Problems? Springer, Amsterdam, The Netherlands, 2013.

[56] X. Wang, D. Varady, and Y. Wang, "Measuring the deconcentration of housing choice voucher program recipients in eight U.S. metropolitan areas using hot spot analysis," Cityscape, vol. 10, no. 1, pp. 65-90, 2008.

[57] S. J. Popkin, D. K. Levy, E. H. Laura, J. Comey, M. K. Cunningham, and L. Buron, "HOPE VI panel study: Baseline Report," Final Report, The Urban Institute, Washington, DC, 2002.

[58] B. A. Jacob, "Public housing, housing vouchers, and student achievement: evidence from public housing demolitions in Chicago," The American Economic Review, vol. 94, no. 1, pp. 233258, 2004.

[59] M. Joseph and R. Chaskin, "Living in a mixed-income development: resident perceptions of the benefits and disadvantages of two developments in Chicago," Urban Studies, vol. 47, no. 11, pp. 2347-2366, 2010.

[60] E. G. Goetz, "Housing dispersal programs," Journal of Planning Literature, vol. 18, no. 1, pp. 3-16, 2003.

[61] M. K. Cunningham and A. Droesch, Neighborhood Quality and Racial Segregation, The Urban Institute, Washington, DC, USA, 2005.

[62] G. T. Kingsley, J. Johnson, and K. L. S. Pettit, "Patterns of section 8 relocation in the HOPE VI program," Journal of Urban Affairs, vol. 25, no. 4, pp. 427-447, 2003.

[63] M. Finkel and L. Buron, Study on Section 8 Voucher Success Rates: Volume 1 Quantitative Study of Success Rates in Metropolitan Areas, Abt Associates, Cambridge, Mass, USA, 2001.

[64] R. Pendall, "Why voucher and certificate users live in distressed neighborhoods," Housing Policy Debate, vol. 11, no. 4, pp. 881910, 2000.

[65] P. D. Tegeler, "The persistence of segregation in government housing programs," in Geography of Opportunity, X. D. S. Briggs, Ed., pp. 197-218, Brookings Institution Press, Washington, DC, USA, 2005.

[66] A. H. Charney, "Migration and the public sector: a survey," Regional Studies, vol. 27, no. 4, pp. 313-326, 1993.

[67] F. B. Glantz, "The determinants of the intermetropolitan migration of the poor," The Annals of Regional Science, vol. 9, no. 2, pp. 25-39, 1975.

[68] R. L. Forstall and R. P. Greene, "Defining job concentrations: the Los Angeles case," Urban Geography, vol. 18, no. 8, pp. 705-739, 1997.

[69] R. P. Greene, "Strong downtowns and high amenity zones as defining features of the 21st century metropolis: the case of Chicago," in Chicago's Geographies: Metropolis for the 21st Century, R. P. Greene, M. J. Bouman, and D. Grammenos, Eds., Association of The American Geographers, Washington, DC, USA, 2006.
[70] T. W. Sanchez, "The connection between public transit and employment: the cases of Portland and Atlanta," Journal of the American Planning Association, vol. 65, no. 3, pp. 284-296, 1999.

[71] Illinois Assisted Housing Action Research Project (IHARP), "Are we home yet? Creating real choice for housing choicevoucher families in Chicago," 2010, http://www.uic.edu/cuppa/ voorheesctr/Publications/IHARP20HCV20Report202010.pdf 573cac0a804d46f4al4d2fc965ee50e9.pdf.

[72] J. F. Kain, "Housing segregation, Negro employment, and metropolitan decentralization," Quarterly Journal of Economics, vol. 82, no. 2, pp. 175-197, 1968.

[73] W. J. Wilson, The Truly Disadvantaged: The Inner City, the Underclass, and Public Policy, University of Chicago Press, Chicago, Ill, USA, 1987.

[74] R. Price and E. Mills, "Race and residence in earnings determination," Journal of Urban Economics, vol. 17, no. 1, pp. 1-18, 1985.

[75] M. A. Stoll, H. J. Holzer, and K. Ihlanfeldt, "Within cities and suburbs: Racial residential concentration and the spatial distribution of employment opportunities within sub-metropolitan areas," Department of Policy Studies, UCLA, 1998.

[76] D. S. Massey and N. A. Denton, "The dimensions of residential segregation," Social Forces, vol. 67, no. 2, pp. 281-315, 1988.

[77] I. M. Young, "Residential segregation and differentiated citizenship," Citizenship Studies, vol. 3, no. 2, pp. 237-252, 1999.

[78] P. A. Jargowsky, "Response to George C. Galster's 'Consequences from the redistribution of urban poverty during the 1990s: a cautionary tale,' Economic Development Quarterly, vol. 19, no. 2, pp. 133-135, 2005.

[79] T. J. Phelan and M. Schneider, "Race, ethnicity, and class in American suburbs," Urban Affairs Review, vol. 31, no. 5, pp. 659680, 1996.

[80] J. R. Logan, R. D. Alba, and S.-Y. Leung, "Minority access to white suburbs: a multiregional comparison," Social Forces, vol. 74, pp. 851-881, 1996.

[81] A. M. Holloway, "Affordable housing in Chicago: the duPage county experience," in Policy Profiles, Northern Illinois University, Center for Governmental Studies, DeKalb, Ill, USA, 2008.

[82] E. S. Shihadeh and M. O. Maume, "Segregation and crime: the relationship between black centralization and urban black homicide," Homicide Studies, vol. 1, no. 3, pp. 254-280, 1997.

[83] S. W. Allard, Access to Services: The Changing Urban Geography of Poverty and Service Provision, Brookings Institution, Washington, DC, USA, 2004.

[84] W. Batchis, "Suburbanization and constitutional interpretation: exclusionary zoning and the supreme court legacy of enabling sprawl," Stanford Journal of Civil Rights and Civil Liberties, vol. 8, no. 1, p. 1, 2012.

[85] J. T. Rothwell, "Racial enclaves and density zoning: the institutionalized segregation of racial minorities in the United States," The American Law and Economics Review, vol. 13, no. 1, pp. 290358, 2011.

[86] J. T. Rothwell and D. S. Massey, "Density zoning and class segregation in U.S. metropolitan areas," Social Science Quarterly, vol. 91, no. 5, pp. 1123-1143, 2010.

[87] H. L. Golz, "Breaking into affluent Chicago suburbs: an analysis of the Illinois affordable housing planning and appeal act," Journal of Affordable Housing and Community Development Law, vol. 15, no. 2, pp. 181-213, 2006.

[88] Illinois Housing and Development Authority (IHDA), Affordable Housing Planning and Appeal Act, Illinois Housing Development Authority, Springfield, Ill, USA, 2011. 
[89] D. Rice, "Senate HUD funding bill reverses harmful sequestration cuts in housing assistance," Center on Budget and Policy Priorities, 2013, http://www.cbpp.org/files/7-19-13hous.pdf.

[90] S. Reckhow and M. Weir, Building a Stronger Regional Safety Net and Philanthropy's Role, Brookings Institution, Washington, DC, USA, 2011. 

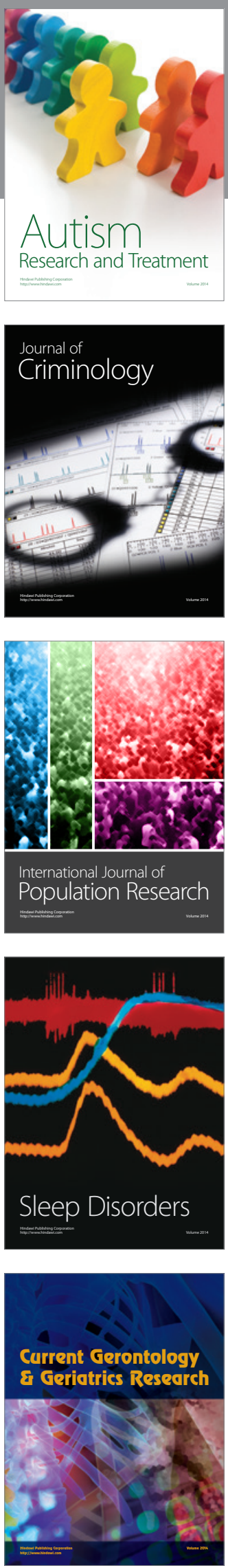
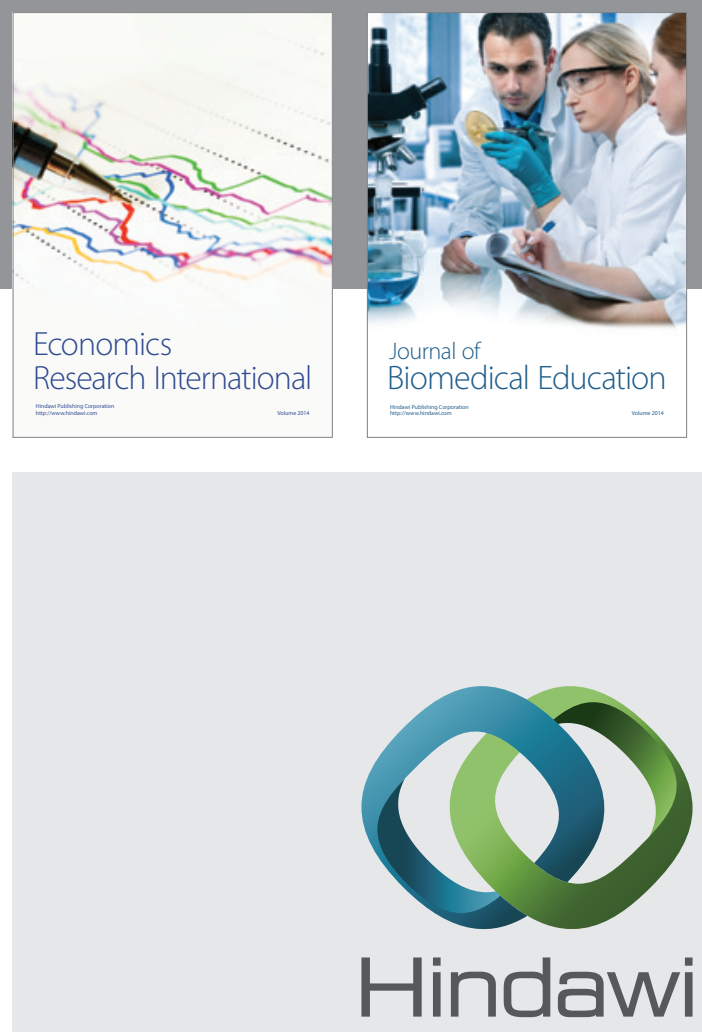

Submit your manuscripts at

http://www.hindawi.com
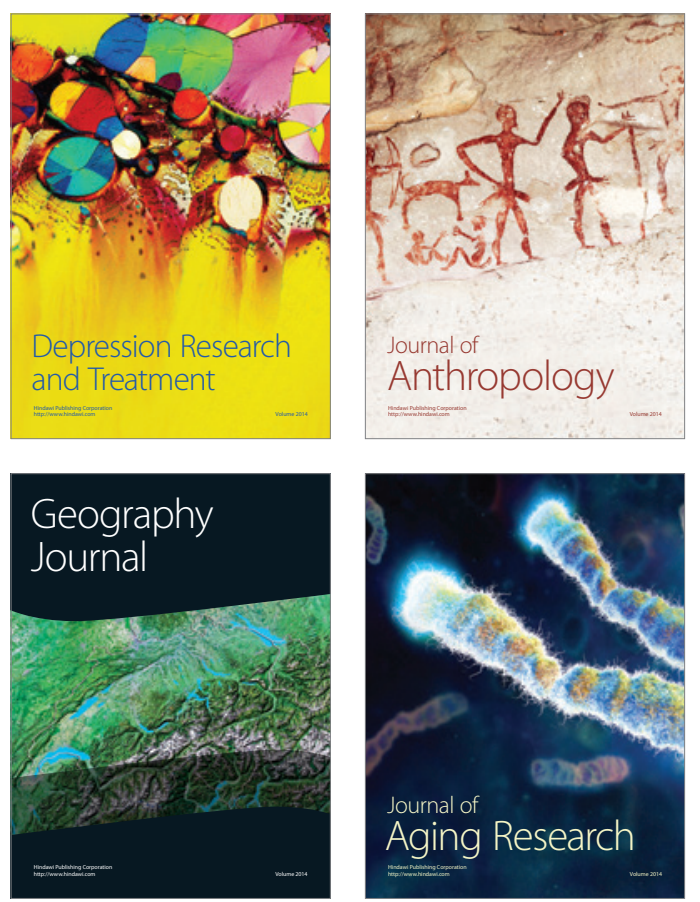
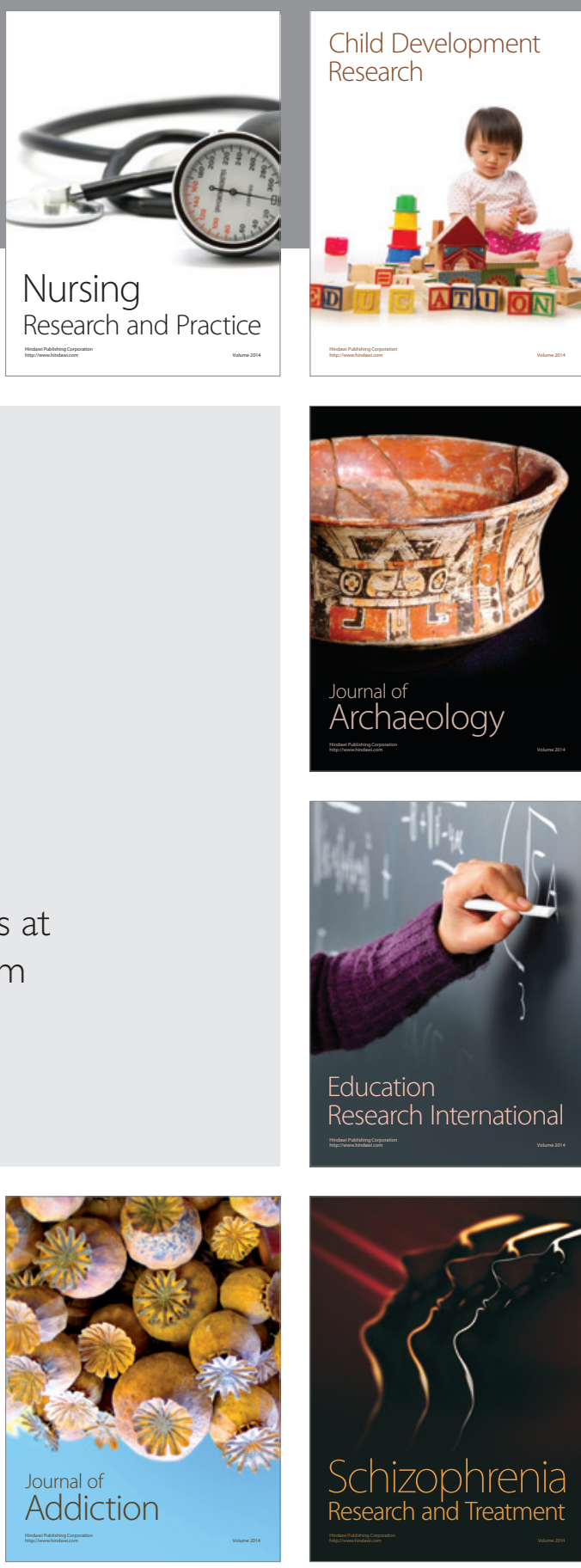

(D)
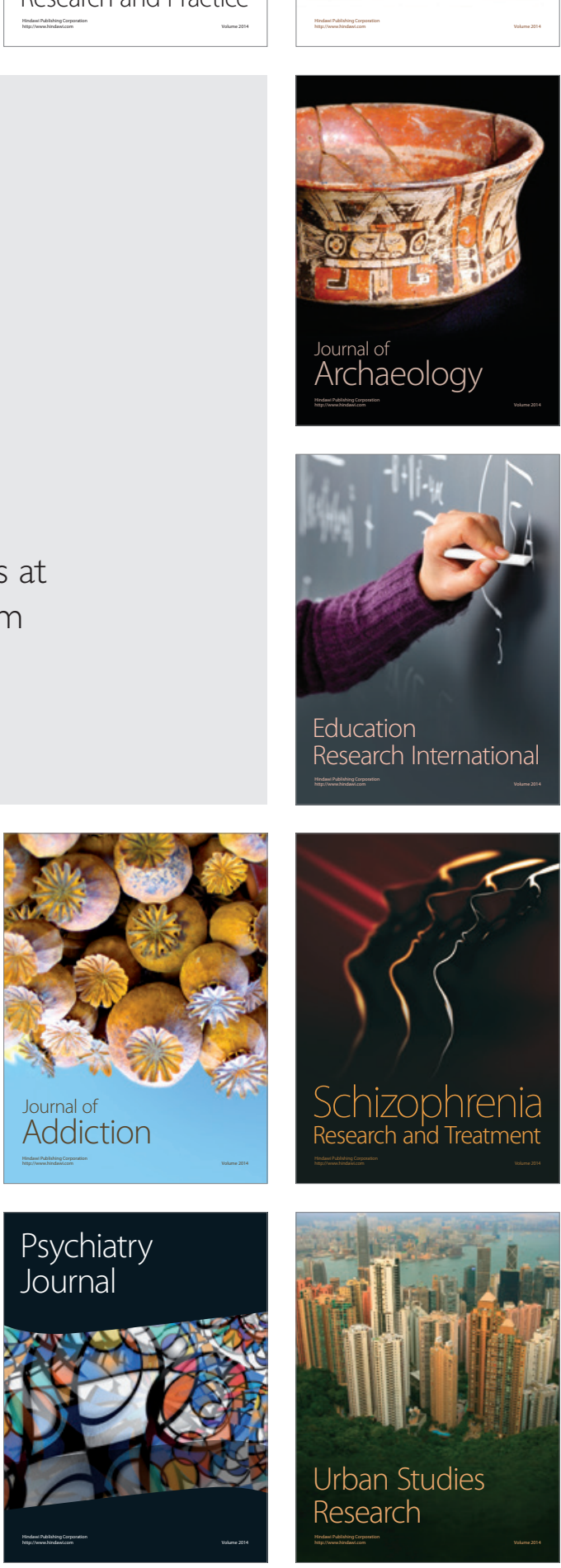